\title{
Understanding the value proposition as a cocreated claim
}

\author{
Noelle London \\ University of Texas at Austin \\ london.noelle@gmail.com
}

\author{
Gregory Pogue \\ IC $C^{2}$ Institute \\ gpogue@ic2.utexas.edu
}

\author{
Clay Spinuzzi \\ University of Texas at Austin \\ clay.spinuzzi@utexas.edu
}

\begin{abstract}
In this paper, we examine five cases of technology commercialization in terms of how entrepreneurs advance a specific kind of claim: the value proposition. The value proposition can describe the characteristics of the innovation itself (GoodsDominant Logic) or propose how the innovation will cocreate value with stakeholders (Service-Dominant Logic); in the examined cases, the value proposition transitions between these two "logics," addressing different needs in the ongoing argument. We conclude by discussing the needs that each "logic" serves and the implications for better understanding entrepreneurship communication
\end{abstract}

Index Terms - entrepreneurship, value proposition, Goods-Dominant Logic, Service-Dominant Logic, technology commercialization

\section{INTRODUCTION}

In 2008, a small Korean company we will call Firm A sought to commercialize its technology for the global market. This technology was a coated brake spring for automobiles. Here is how Firm A characterized its initial value proposition - its claim about the value of a product or process for an audience in a specific market: "This technology is a brake pad spring that reduces friction, improves corrosion resistance, and reduces high frequency vibrations \& noise. Invented for the purpose of reducing noise and friction in automotive brake systems, the innovation is based on a combination of coatings which provide dampening and reduced friction in a targeted manner while also improving corrosion resistance."

That is, the value proposition described an aesthetic improvement: it eliminated extra noise and friction, incrementally improving the quality of the spring. This product-focused description represented a defined solution for a defined problem.

But in 2009, Toyota began to recall cars to address a malfunction in which floormats were becoming stuck under the accelerator. The resulting news stories made both the consumer market and original equipment manufacturers (OEMs) more sensitive to brake issues. Firm A was able to seize the opportunity by pivoting, repositioning its value proposition to address this emergent safety concern: It proposed that by reducing friction, the coating could lengthen the life of the brake spring and therefore improve safety. This once-failing company soon became a global supply leader in the brakes market.

This case illustrates how an entrepreneur must iterate the value proposition. As the case shows, value propositions may change considerably in a short period of time. Partly that's because "value" is relative to the audience, and there are many audiences (stakeholders) in entrepreneurship, positioned differently in different stages, different industries and cycles. Often, as in Firm A's case, that positioning changes from (a) describing a solution to a defined problem to (b) proposing a solution to an emergent problem, based on dialogue with stakeholders.

In this paper, we examine the value proposition rhetorically, as a kind of claim about the innovation. This claim is founded on assumptions about how the audience relates to the described innovation, and that assumed relationship changes at different parts of the entrepreneurship process. We examine four cases of technology commercialization in terms of how entrepreneurs advance value propositions, focusing on how their value propositions move between two sets of assumptions (or "logics") to address different needs in the ongoing argument. We conclude by discussing the needs that each "logic" serves and the implications for better understanding this aspect of entrepreneurial rhetoric.

\section{BACKGROUND AND LITERATURE REVIEW}

\section{Entrepreneurship, Training, and the GCG}

Firm A and the other entrepreneurs discussed in this paper were technological innovators working in the Korean market. These innovators wished to expand into the global market; to learn how to do so, they entered training programs structured as pitch competitions. These 
programs were run by the Global Commercialization Group (GCG) of the $\mathrm{IC}^{2}$ Institute, an interdisciplinary research unit at The University of Texas at Austin. GCG facilitates the development of technology-based businesses worldwide by providing experience and training as well as facilitating links to international markets, with the goal of sustained commerce. (See Gibson \& Conceicao [1] for an overview of such programs and Spinuzzi et al. [2] for a review of this specific one.)

In these training programs, GCG selects applicants with promising technologies, provides training and market information for them, and works with the most promising innovators (such as Firm A) to help them connect with global target markets. In the process, it helps them to refine the complex set of arguments they must make. Entrepreneurs must make and support several interrelated claims about the innovation, its intended markets, the team that will bring it to market, and the business models and financials that will support it (cf. Moore [3]; Blank [4]; Spinuzzi et al. [2]).

But the entrepreneur's core argument is the value proposition. What do potential stakeholders value, and how can this innovation help them to address that value? That is, what will convince them to become stakeholders? The term "value proposition," first coined in 1984 (Lanning \& Michaels [5]), usually helps to explain what a product is, who the target customer is, and what value the firm provides. In Crossing the Chasm, Geoffrey Moore says, "Positioning [value proposition] is the single largest influencer of decisions," yet "Even though positioning is one of the most discussed aspects of marketing, it is the least understood" ([3], p.48). Indeed, firms that hope to commercialize globally, such as those that participate in GCG programs, provide interesting cases, since globalizing naturally forces entrepreneurs to evolve their value propositions: as Moore argues, the value proposition must adapt if exposed to new conditions ([3], p. 100).

Surprisingly few studies exist that examine entrepreneurship communication from a professional communication standpoint (e.g., Doheny-Farina [6]; Fraiberg [7]; Galbraith et al. [8]; Hixson and Paretti [9]; O’Connor [10]; Spinuzzi [11]; Spinuzzi et al. [2]). And as far as we know, none address the value proposition rhetorically. However, some theoretical work in marketing can help us characterize this sort of claim.

\section{Two Perspectives on the Value Proposition: Goods- Dominant Logic and Service-Dominant Logic}

To better characterize the value proposition as a claim, we must understand the "logic" or assumptions that underpin it. We turn to marketing theory, specifically service-dominant logic (SDL) (Lusch and Vargo [12]; Ballantyne et al. [13]; Kowalkowski [14]; Lusch and Webster [15]; Skalen et al. [16]; Vargo \& Lusch 17]), to characterize this logic.

Lusch and Vargo ([12], pp. 4-5) argue that marketing has assumed what they call goods-dominant logic (GDL or "G-D logic"), in which value is understood as embedded in goods and offered to consumers: "This logic frames the world of exchange in terms of units of output (goods). Others have referred to it as 'old enterprise logic,' 'manufacturing logic,' and other, similarly descriptive tags." According to the authors, GDL "views the production and exchange of goods as the central components of business and economics. That is, it frames the purpose of the firm and the function of economic exchange in terms of making and distributing products units of output, usually tangible. It is closely aligned with neoclassical economics, which views actors as rational, firms as profit-maximizing, customers as utilitymaximizing, information and resources as flowing easily among economic actors, and markets as equilibriumseeking - scholars within and outside economics have challenged all these perspectives." (p.4; see Zuboff and Maxmin [18] for a similar argument)

G-D logic, they say, developed from economics and inherited economics' focus on exchange-value, a focus that can be traced back to the limitations and peculiarities that Adam Smith dealt with in his famous treatise The Wealth of Nations (Lusch \& Vargo [12], pp.6-7). This logic is focused on goods (products), describing them in generic market criteria: cost, quality, and speed. These generic criteria allow customers to easily compare goods. For instance, if I have a new manufacturing process, I might focus on describing how that process produces widgets faster, cheaper, and of higher quality than competing processes; customers can then compare different processes across these three generally applicable criteria.

But, the authors argue, Adam Smith used exchangevalue as a proxy for use-value (p.7), that is, the value that goods bring to specific customers. Focusing on use-value, they argue, means that we must acknowledge that "value is cocreated" among all entities involved in the transaction (p.8). That entails seeing each transaction as a service rather than a good, a service in which we must recognize "the most important resources being integrated and doing the integration - human actors with their skills, knowledge, and innovative and entrepreneurial abilities. What is needed is a logic that, rather than abandoning goods logic, transcends it, by recognizing the primacy of human resources applied for the benefit of others (and ourselves) - service" (p.8).

Lusch and Vargo call this second logic servicedominant logic (SDL or "S-D logic"). Whereas GDL saw the relationship as being between producers and 
consumers, SDL removes that distinction: "Fundamentally, all actors (e.g., business firms, nonprofit and government organizations, individuals, and households) have a common purpose: value cocreation through resource integration and service-for-service exchange" ([12], p.10). "This service-oriented interpretation focuses attention on the only resource the actors really possess to take to market: their own knowledge and skills" (p.11). And thus, the authors say, we get to the key difference in understanding the business process: between "selling things to people and understanding it as serving the exchange partner's needs. This difference is a key difference between G-D and S-D logic" (p.11). Under SDL, value is customized: rather than being assessed under the generic and easily comparable criteria of cost, quality, and speed, it is assessed by criteria that are unique to a specific customer's needs. Critically, those needs are discovered through dialogue and feedback: although the firm may propose a value proposition, the customer interprets value proposition and provides feedback, which helps influence the creation of these solutions and experiences (Vargo and Lusch [17]). Thus, they argue, because value proposition depends on dialogue, the firm becomes a co-creator of value. The objective of the firm is to sell experience (Lusch and Vargo [12]).

Lusch and Vargo argue that under SDL, the value proposition is a specific type of claim: "a value proposition under S-D logic is how an actor co-proposes to positively affect another actor. This recognizes that value is obtained when an actor experiences through engagement with the firm the unfolding of the interactive market offering. Stated alternatively, firms and other actors can offer potential value through value propositions; however, they cannot create value but only cocreate it." Under SDL, "Value propositions are therefore promises but they must be fulfilled. Firms and actors, in general in developing exchange relationships, should view their role as offering more compelling value propositions than other competing actors but then making sure, to the extent possible, that actual value as experienced by the beneficiary meets or exceeds promised value" ([12], p.72, their emphasis).

In short, we can see the value proposition in rhetorical terms as a claim that can alternately function under two different logics:

- Under GDL, the claim describes how a good's characteristics, embedded by the producer, meet generic criteria.

- Under $S D L$, the claim proposes how a service's benefits, cocreated by the producer and customer, meet the customer's unique needs. By providing feedback on the value proposition, the customer plays an active role in cocreation (Ballantyne et al. [13], p 206); the customer and firm collaborate with each other to share information about value (Rust [19]; Kristensson et al. [20]; Vargo et al [21]). The result of this dialogue is a set of criteria that uniquely address the customer's needs.

These two logics are different, but both are useful for entrepreneurs such as Firm A. In fact, we argue that these two kinds of value propositions are interrelated claims, leveraged at different points in the process of developing an argument. That is, the claim (the value proposition) is co-creatively iterated by shifting from GDL to SDL assumptions. That iteration, we argue, can occur across the entire customer development process.

\section{The Customer Development Process: The Four Steps to the Epiphany}

In his enormously influential book The Four Steps to the Epiphany [4], Steve Blank argues that customer development occurs in four sequential but iterated stages: (1) customer discovery, (2) customer validation, (3) customer creation, and (4) company building. In steps 1-2 (the "Search" phase), entrepreneurs search for the right business model and test value propositions as hypotheses; in steps 3-4 (the "Execute" phase), entrepreneurs execute based on the business model and the validated value proposition. That is, in rhetorical terms, the essential claim is established in the first two steps, then serves as the foundation for the last two steps.

But we argue that the value proposition can also be iterated and developed during the "execute" phase. That is, the claim is still fluid, and in some cases (such as Firm A's), it must be: for the technology to be taken up by stakeholders, it must be not just diffused (transported) but translated (adapted to local conditions and concerns) (see Akrich et al. [22] and Latour [23] for sociological discussions of this point, and Rogers [24] for a related discussion within the diffusion literature). Below, we illustrate this argument by examining four cases in which entrepreneurs developed value propositions.

\section{METHODS}

To explore this issue, the first author conducted retrospective interviews with four business developers who supported five entrepreneurs in GCG's training programs (Table 1). Four companies were selected because their arguments involved significant changes in the value proposition, allowing us to compare the different versions; the fifth was selected as a contrasting case in which the value proposition did not change.

The authors also examined ancillary materials provided by and for the entrepreneurs, including applications to their training programs, drafts of pitch slide decks, and technology assessment and commercialization reports (see also Spinuzzi et al. [2]). 
This investigation was part of a multiyear project that was approved by the third author's institutional review board.

TABLE 1. FIRMS IN THIS STUDY. NAMES OF FIRMS AND INTERVIEWEES ARE PSEUDONYMS.

\begin{tabular}{|c|c|c|}
\hline Firm & Technology description & $\begin{array}{l}\text { Interviewees } \\
\text { (Pseudonyms) }\end{array}$ \\
\hline $\begin{array}{l}\text { Firm } \\
\text { A }\end{array}$ & Coated brake spring & Lyle; Byul \\
\hline $\begin{array}{l}\text { Firm } \\
\text { B }\end{array}$ & $\begin{array}{l}\text { Process to produce } \\
\text { aluminum in a rounded } \\
\text { shape in a single process }\end{array}$ & Lyle; Byul \\
\hline $\begin{array}{l}\text { Firm } \\
\mathrm{C}\end{array}$ & $\begin{array}{l}\text { Reliability and durability } \\
\text { testing systems }\end{array}$ & Lyle; Byul \\
\hline $\begin{array}{l}\text { Firm } \\
\text { D }\end{array}$ & Noise cancellation software & Abe, Alan; Lyle \\
\hline $\begin{array}{l}\text { Firm } \\
\text { E }\end{array}$ & $\begin{array}{l}\text { Machine to heat baby } \\
\text { formula }\end{array}$ & Lyle; Alan \\
\hline
\end{tabular}

Below, we discuss our findings.

FINDINGS

As Table 2 shows, the firms each iterated their value propositions during the execution phase.

TABLE 2. FIRMS, TECHNOLOGIES, AND VALUE PROPOSITIONS.

\begin{tabular}{|l|l|l|l|}
\hline Firm & $\begin{array}{l}\text { Technology } \\
\text { description }\end{array}$ & $\begin{array}{l}\text { Initial Value } \\
\text { Proposition }\end{array}$ & $\begin{array}{l}\text { Final Value } \\
\text { Proposition }\end{array}$ \\
\hline $\begin{array}{l}\text { Firm } \\
\text { A }\end{array}$ & $\begin{array}{l}\text { Coated brake } \\
\text { spring }\end{array}$ & $\begin{array}{l}\text { Reduces noise } \\
\text { and friction in } \\
\text { automotive } \\
\text { brake systems }\end{array}$ & $\begin{array}{l}\text { Greater brake } \\
\text { safety through } \\
\text { corrosion- } \\
\text { resistant brake } \\
\text { springs }\end{array}$ \\
\hline $\begin{array}{l}\text { Firm } \\
\text { B }\end{array}$ & $\begin{array}{l}\text { Process to } \\
\text { produce } \\
\text { aluminum in } \\
\text { a rounded } \\
\text { shape in a } \\
\text { single } \\
\text { process }\end{array}$ & $\begin{array}{l}\text { Improves } \\
\text { productivity } \\
80 \%, \text { lowers } \\
\text { selling price } \\
30 \%\end{array}$ & $\begin{array}{l}\text { A seamless, } \\
\text { one piece } \\
\text { muffler that } \\
\text { does not crack } \\
\text { along weld } \\
\text { joints, leading } \\
\text { to significant } \\
\text { cost savings }\end{array}$ \\
\hline $\begin{array}{l}\text { Firm } \\
\text { C }\end{array}$ & $\begin{array}{l}\text { Reliability } \\
\text { and }\end{array}$ & $\begin{array}{l}\text { Manufactures } \\
\text { testing }\end{array}$ & $\begin{array}{l}\text { Provides test } \\
\text { bench }\end{array}$ \\
\hline
\end{tabular}

\begin{tabular}{|l|l|l|l|}
\hline & $\begin{array}{l}\text { durability } \\
\text { testing } \\
\text { systems and } \\
\text { services }\end{array}$ & $\begin{array}{l}\text { equipment at a } \\
\text { lower cost than } \\
\text { its main } \\
\text { competitors, } \\
\text { offers strong } \\
\text { technical } \\
\text { services abilities } \\
\text { and after-sale } \\
\text { support }\end{array}$ & $\begin{array}{l}\text { facilities and } \\
\text { services for a } \\
\text { partner (and } \\
\text { former } \\
\text { competitor) in } \\
\text { the US }\end{array}$ \\
\hline $\begin{array}{l}\text { Firm } \\
\text { D }\end{array}$ & $\begin{array}{l}\text { Noise } \\
\text { cancellation } \\
\text { software }\end{array}$ & $\begin{array}{l}\text { Reduces } \\
\text { ambient noise in } \\
\text { cell phones, } \\
\text { improves battery } \\
\text { life }\end{array}$ & $\begin{array}{l}\text { Reduces } \\
\text { ambient noise } \\
\text { in drive- } \\
\text { through PA } \\
\text { system for an } \\
\text { international } \\
\text { fast food } \\
\text { chain }\end{array}$ \\
\hline $\begin{array}{l}\text { Firm } \\
\text { E }\end{array}$ & $\begin{array}{l}\text { Machine to } \\
\text { heat baby } \\
\text { formula }\end{array}$ & $\begin{array}{l}\text { Automatically } \\
\text { mix formula } \\
\text { with heated } \\
\text { water to the } \\
\text { perfect } \\
\text { temperature in } \\
90 \text { seconds }\end{array}$ & (Same) \\
\hline
\end{tabular}

Firm A, discussed earlier, produced a coated brake spring for automobiles; the coating process reduced noise and friction and consequently extended the life of the spring. Firm B developed a process to produce aluminum in a rounded shape in a single process, which dramatically improved productivity but also made it possible to produce such pieces without weld joints. Firm $\mathbf{C}$, a "nontypical participant" according to our interviewee, manufactured testing equipment and provided testing services in Korea; eventually, it entered a joint partnership with its largest competitor to provide testing services in the US, achieving a bigger market for both firms. Firm D produced software for reducing ambient noise, originally pitched to the mobile phone market but with applications in other areas. Finally, Firm E presented what was glossed as a "baby formula cappuccino maker"; although interested partners could see connections with their own value propositions, Firm E did not adjust its value proposition to pair with potential partners. Later, business developers discovered that Firm $\mathrm{E}$ had deceived them about the readiness of the technology: although Firm E told Alan that it was ready to go to market within three months, it only had a prototype, did not hold manufacturing partnerships, and could not manufacture units at the promised price.

Innovators typically enter GCG training programs with product-based (GDL) perspectives and express descriptive, GDL-oriented value propositions. Yet, to 
successfully commercialize innovations, these innovators must evolve the value proposition to an experience-based (SDL) perspective through a cocreation process with customers; they must identify a problem or market pain that customers have and that the innovation can help them to solve. Through business development and training, innovators are typically able to evolve their understanding of value proposition into an SDL perspective.

Through our investigation, we found that, for Firms A$\mathrm{D}$,

- Value propositions were iterated during the execution phase

- Iterating value propositions involved transitioning from GDL to SDL arguments

\section{Value propositions were iterated during execution} phase

All five firms were past their "search" phase and into their "execution" phase, a phase in which we would expect them to be done with iterating the value proposition, according to Blank's model [2013]. Yet for Firms A-D, the value proposition changed "constantly" (as Alan characterized D). For Firm E, the value proposition was not explicitly articulated; Alan stated that Firm E did not go past the feature description to articulate benefits. Alan suggested that the value proposition could have been: "you had something that created a perfect temperature formula for your baby, and you had the piece of mind that in your sleepy state you weren't going to burn your baby."

Table 2 shows how Firms A-D changed their stated value propositions during their business development period. For instance, Firm B produced a technical innovation in the production of aluminum products. Previously, aluminum products were produced by stamping several separate parts and connecting them to make a rounded shape; for instance, making the rounded tubular shape of a muffler traditionally involved 5-15 different and expensive processes. However, Firm B created an advanced production system that produced aluminum in a rounded shape in a single process. This innovation simplified the process line and helped mitigate environmental pollution when manufacturing parts. This advanced process solved three key issues in the production: the forming process, the process of curving the hole, and the washing process. Firm B initially described the value proposition in product-oriented terms: it improved productivity by $80 \%$ (speed) and lowered the selling price by $30 \%$ (cost) compared to the standard method.

But as Firm B moved into the execution phase, it conducted a dialogue with potential customers, drawing on their experience to co-identify a much more important problem to which they could propose a co-created solution. The problem was a weakness in air conditioning mufflers made through the standard method.
Traditionally, these mufflers are made in three separate pieces: two sides and a bulb, which were then welded together. The welding created a weakness, leading to cracking and leakage in the mufflers. By developing a seamless process, Firm B was able to offer mufflers without this weakness, leading to long-term durability and therefore long-term cost savings - a value proposition that Firm B could not have offered on its own. That is, Firm B proposed a customized solution to a specific customer problem.

Similarly, Firm D produced noise cancellation software that "picks up specifically on mid-field sounds and effectively eliminates the remaining sounds (even near field, or less than 12 inches)" (Alan interview). As Lyle told us, most voice recognition tries to amplify the dominant signal; Firm D's software suppresses the nondominant signal, meaning that they could use just one microphone. Applied to a mobile phone, this change potentially saves $60 \%$ of battery life; this battery savings (quality) was Firm D's original value proposition, a GDLperspective value proposition that was oriented to a specific product and yielded incremental benefits compared to the current design.

However, as Abe recounted, those benefits were outweighed by the redesign costs for handset manufacturers. Instead, the business developers looked at similar cases in which customers needed noise reduction, starting with videoconferencing and examining the entire product line of a communications equipment manufacturer. Abe explained: "By doing a little bit of research, we learned that [the equipment manufacturer] was bidding with [a fast food chain] to replace all of their intercom equipment. In the past, when you went through the drive-through, with kids in the backseat and the radio on, and you have this horrible speaker phone on the outside panel, you can't understand, it's horrible. As a business, not only would it cause delays but also it would cause mistakes due to misunderstanding. This provided something that eliminated the far noise (the traffic) and eliminate some of the mid-range noise (the kids yelling). The driver in the car now only hears the person taking the order as opposed to all of the background noise in the restaurant, like clanking in the kitchen or other customers ordering at the register. To do that well is magical. That can really help a company's bottom line by getting their orders 10 seconds faster." This problem is so endemic in the fast food industry that one chain has begun deploying "human" microphone systems (employees with wireless tablets, standing next to the drive-through lane) to take orders in place of the intercom.

Based on this insight, Firm D was able to create a dialogue that helped them to better understand the needs of the industry and cocreate a new value proposition: not an incremental savings in battery life, but long-term cumulative savings in company and consumer time as well as reduced frustration and a better consumer 
experience. The new value proposition, cocreated with the customers, provided far more significant value.

\section{Iterating value propositions involved transitioning from $G D L$ to $S D L$ arguments}

In all cases, the original value propositions were based on GDL: they described characteristics of a technology, treating the technology as a defined solution to a defined problem. Firm A focused on brake noise reduction; Firm $\mathrm{B}$ offered time and cost savings in manufacturing; Firm $\mathrm{C}$ offered less expensive testing equipment; Firm D offered battery savings in handsets; and Firm E focused on the technical description of the product's features. Each of these value propositions offered incremental improvements in cost, quality, and speed. Each assumed that the value proposition is meant to communicate to the customer, describing the product's characteristics, assuming that the producer can determine value, and assuming that the value is defined at the point of exchange (Lusch and Vargo [12], pg. 9, Exhibit 1.2).

However, Firms A-D engaged in market dialogue (Ballantyne et al. [13]; Kowalkowski et al. [14], and in doing so, shifted to value propositions based on an SDL perspective. These new value propositions focused on how the technology provided a new service. For instance, as discussed above, Firms A, B, and D found through dialogue with their potential customers that their technologies could address "market pain" or specific problems of which they were initially unaware: safety, durability, and large-scale increases in customer service quality. Firm $\mathrm{C}$ found that it could dissociate its technical service component from its product, allowing it to reach new markets through a partnership. The new value propositions emerged from collaboration with customers, proposing how a service can address the customer's experience, iterating the value along with the customer, and assuming that the value is determined through use (Table 3).

That is, in iterating their value proposition claims, Firms A-D used their dialogue with the market to shift to a different set of assumptions underpinning these claims. The claims had to change from descriptions to proposals because their assumptions about value changed.

TABLE 3. TRANSITIONING BETWEEN GDL AND SDL IN CASES.

\begin{tabular}{|l|l|l|}
\hline $\begin{array}{l}\text { Goods- } \\
\text { dominant logic }\end{array}$ & $\begin{array}{l}\text { Role of } \\
\text { dialogue/process }\end{array}$ & $\begin{array}{l}\text { Service- } \\
\text { dominant logic }\end{array}$ \\
\hline $\begin{array}{l}\text { Interaction: } \\
\text { communicate to } \\
\text { customer }\end{array}$ & Coordination & $\begin{array}{l}\text { Interaction: } \\
\text { collaborate with } \\
\text { customer }\end{array}$ \\
\hline Value & Understanding & Value \\
\hline
\end{tabular}

\begin{tabular}{|l|l|l|}
\hline $\begin{array}{l}\text { proposition is } \\
\text { product-based } \\
\text { possibilities }\end{array}$ & $\begin{array}{l}\text { proposition is } \\
\text { experience- } \\
\text { based }\end{array}$ \\
\hline $\begin{array}{l}\text { Role of firm } \\
\text { determines value }\end{array}$ & Feedback & $\begin{array}{l}\text { Value is co- } \\
\text { created by firm } \\
\text { and customer. }\end{array}$ \\
$\begin{array}{l}\text { Firm only } \\
\text { proposes value } \\
\text { proposition, } \\
\text { customer } \\
\text { feedback } \\
\text { contributes to } \\
\text { cocreation of } \\
\text { value }\end{array}$ \\
\hline $\begin{array}{l}\text { Value is defined } \\
\text { at the point of } \\
\text { exchange } \\
\text { (provides } \\
\text { benefits) } \\
\text { (goods/services) }\end{array}$ & $\begin{array}{l}\text { Finding risks and } \\
\text { efforts to } \\
\text { understand pain } \\
\text { and gain }\end{array}$ & $\begin{array}{l}\text { Value } \\
\text { determined } \\
\text { through use } \\
\text { (solutions and } \\
\text { experiences) }\end{array}$ \\
\hline
\end{tabular}

As the above implies, this shift is a rhetorical, argumentative shift. The GDL-based value propositions were communicated to the customer; the SDL-based value propositions were co-created with the customer. That is, GDL-based value propositions aim to convince customers to buy a product; SDL-based value propositions result from working with customers to develop a mutually agreeable claim.

In contrast, although the business developer set up dialogue between Firm E and four major US retailers, Firm E did not attempt to iterate its value proposition: it continued describing its product's (notional) features rather than revising the value proposition in response to dialogue. As Alan told us, one major retailer's "value proposition to members is that they bring products to the market that are unique and improve people's lives. They sell those products at a cost that is attractive. The value prop of [Firm E's] product had to sit within the company's value proposition." Note that this potential SDL rearticulation of the value proposition had nothing to do with Firm E's deception: Firm E could have easily iterated its value proposition claim even though the technology was not ready for market. The idea itself is compelling. (In fact, at the time of writing, a firm with a similar product is currently soliciting investment on Kickstarter.)

\section{IMPLICATIONS}

We believe that the argumentative shift from GDL to SDL is significant. Examining the value proposition as a claim allows us to apply rhetorical concepts that can 
illuminate how the shift occurs. Specifically, we believe that these two different "logics," GDL and SDL, imply different kinds of, and orientations to, claims.

GDL claims are primarily descriptive and comparative claims formulated by innovators. As we have noted, these claims describe the product itself, comparing it with existing products, primarily in terms of assumed criteria such as cost, quality, and speed-generic, known criteria that solve generic, known problems. That is, the claims are descriptive because the innovators making those claims have assumed that they address generic problems that customers and innovators understand in the same way. Such claims therefore tend to focus on incremental improvements along these known criteria, such as quieter brakes or longer battery life. These claims address socalled "red ocean" markets, which are established markets in which competitors compete to introduce incremental innovations with diminishing returns (Kim and Mauborgne [25]; see also Slywotzky [26]). Since these claims address established, generic criteria, innovators can make them without engaging in direct dialogue with specific customers; the claims are assumed to apply to any customer in the target market. That is, these claims amount to a product description, a type of document with which most of these technical innovators are familiar.

In contrast, SDL claims are primarily proposal claims, cocreated by innovators and customers; they emerge when innovators decide to discover customers' problems rather than assuming generic problems. That is, these claims result from dialogue and inquiry in which the innovators have discussed unique challenges with specific customers, then shaped their arguments to demonstrate how those unique challenges (and the unique criteria attached to them) are addressed by the innovation. Consequently, these claims tend to be about qualitative changes rather than incremental improvements; they address so-called "blue ocean" markets that have been newly defined and thus have no other competitors (Kim and Mauborgne [25]; see also Slywotzky [26]). Since these claims address unique criteria, innovators must cocreate them with specific customers through extended dialogue; the claims may be similar for customers with similar needs, but they are nevertheless customized for each customer. Rather than assuming shared values and contexts, these claims result from discovering differences in those assumptions and contexts.

Neither kind of claim is "right" or "wrong." They are useful for different applications: GDL value propositions are oriented to yielding broad, diffuse opportunities in existing and well understood markets, while SDL value propositions are oriented to yielding deep, specific opportunities in newly defined markets. However, the business developers believe, and we agree, that SDL (proposal) claims are more highly developed, oriented to more potentially transformative opportunities, and more difficult to make. The firms studied here were able to transform their value propositions to address such transformative opportunities. They were able to productively pivot (that is, iterate their claims, moving from one logic to another) even in the execution phase of the customer development lifecycle.

In contrasting GDL- and SDL-oriented value proposition claims, we have developed greater insight into how value propositions are constructed and iterated. But we have also illustrated some of the potential for examining the rhetoric of entrepreneurship. Indeed, the seizing of opportunity that defines entrepreneurship is thoroughly rhetorical; entrepreneurs must be able to revise their claims at any point, with specific audiences, for value to be recognized by customers. Professional communication researchers, we believe, can bring valuable new insights to entrepreneurship by mapping, analyzing, and theorizing the complex arguments involved in this important activity.

\section{REFERENCES}

[1] D. V Gibson and P. Conceiçao, "Incubating and Networking Technology Commercialization Centers among Emerging, Developing, and Mature Technopoleis Worldwide," in International Handbook on Innovation, L. V. Shavinina, Ed. Oxford: Elsevier, 2003, pp. 739-749.

[2] C. Spinuzzi, R. S. Nelson, K. S. Thomson, F. Lorenzini, R. A. French, G. Pogue, S. D. Burback, and J. Momberger, "Making the Pitch: Examining Dialogue and Revisions in Entrepreneurs ' Pitch Decks," IEEE Trans. Prof. Commun., vol. 57, no. 3, pp. 158-181, 2014..

[3] G. A. Moore, Crossing the chasm: Marketing and selling high-tech products to mainstream customers. New York: HarperBusiness, 1991.

[4] S. Blank, The Four Steps to the Epiphany, Second. K\&S Ranch, 2013.

[5] M. Lanning and E. Michaels, "A business is a value delivery system," 41, 1988.

[6] S. Doheny-Farina, Rhetoric, Innovation, Technology: Case Studies of Technical Communication in Technology Transfer. Cambridge, MA: MIT Press, 1992.

[7] S. Fraiberg, "Reassembling Technical Communication: A Framework for Studying Multilingual and Multimodal Practices in Global Contexts," Tech. Commun. Q., vol. 22, no. 1, pp. 10 27, Jan. 2013.

[8] C. S. Galbraith, B. C. McKinney, a. F. DeNoble, and S. B. Ehrlich, "The Impact of Presentation Form, Entrepreneurial Passion, and Perceived Preparedness on Obtaining Grant Funding," J. Bus. Tech. Commun., vol. 28, no. 2, pp. 222-248, Dec. 2014. 
[9] C. Hixson and M. C. Paretti, "Texts as Tools to Support Innovation: Using the Business Model Canvas to Teach Engineering Entrepreneurs About Audiences," in Proceedings of the IEEE International Professional Communication Conference 2014, 2014.

[10] E. O’Connor, “Storied Business: Typology, Intertextuality, and Traffic in Entrepreneurial Narrative," J. Bus. Commun., vol. 39, no. 1, pp. 36-54, Jan. 2002.

[11] C. Spinuzzi, "How Nonemployer Firms Stage-Manage AdHoc Collaboration: An Activity Theory Analysis," Tech. Commun. Q., vol. 23, no. 2, pp. 88-114, 2014.

[12] R. F. Lusch and S. L. Vargo, Service-Dominant Logic: Premises, Perspectives, Possibilities. New York: Cambridge University Press, 2014.

[13] D. Ballantyne, P. Frow, R. J. Varey, and A. Payne, "Value propositions as communication practice: Taking a wider view," Ind. Mark. Manag., vol. 40, no. 2, pp. 202-210, Feb. 2011.

[14] C. Kowalkowski, O. Persson Ridell, J. G. Röndell, and D. Sörhammar, "The co-creative practice of forming a value proposition," J. Mark. Manag., vol. 28, no. 13-14, pp. 15531570, Dec. 2012.

[15] R. F. Lusch and F. E. Webster, "A Stakeholder-Unifying, Cocreation Philosophy for Marketing," J. Macromarketing, vol. 31, no. 2, pp. 129-134, Mar. 2011.

[16] P. Skålén, J. Gummerus, C. Koskull, and P. R. Magnusson, "Exploring value propositions and service innovation: a servicedominant logic study," J. Acad. Mark. Sci., Feb. 2014.

[17] S. L. Vargo and R. F. Lusch, "Evolving to a New Dominant Logic for Marketing,” J. Mark., vol. 68, no. 1, pp. 1-17, 2004.

[18] S. Zuboff and J. Maxmin, The support economy: Why corporations are failing individuals and the next episode of capitalism. New York: Penguin Books, 2004.

[19] R. T. Rust, C. Moorman, and G. Bhalla, "Rethinking Marketing," Harvard Business Review, 2010. [Online]. Available: https://hbr.org/2010/01/rethinking-marketing/ar/1. [Accessed: 22-Jan-2015].[20] P. Kristensson, J. Matthing, and N. Johansson, "Key strategies for the successful involvement of customers in the co-creation of new technology-based services," Int. J. Serv. Ind. Manag., vol. 19, no. 4, pp. 474-491, 2008.
[20] P. Kristensson, J. Matthing, and N. Johansson, "Key strategies for the successful involvement of customers in the cocreation of new technology-based services," Int. J. Serv. Ind. Manag., vol. 19, no. 4, pp. 474-491, 2008.

[21] S. L. Vargo, P. P. Maglio, and M. A. Akaka, "On value and value co-creation: A service systems and service logic perspective," Eur. Manag. J., vol. 26, no. 3, pp. 145-152, Jun. 2008.

[22] B. Latour, Aramis, or the Love of Technology. Cambridge, MA: Harvard University Press, 1996.

[23] M. Akrich, M. Callon, and B. Latour, "The key to success in innovation part I: The art of interessement," Int. J. Innov. Manag., vol. 6, no. 2 (June), pp. 187-206, 2002.

[24] E. M. Rogers, Diffusion of Innovations, 5th ed. New York: Free Press, 2003.

[25] W. C. Kim and R. Mauborgne, Blue Ocean Strategy. Boston: Harvard Business School Press, 2005.

[26] A. J. Slywotzky, Value Migration: How to Think Several Moves Ahead of the Competition. Boston: Harvard Business School Press, 1996.

\section{ABOUT THE AUTHORS}

Noelle London is a Graduate Student at the LBJ School of Public Affairs at the University of Texas at Austin. She is currently studying global policy related to innovation. As a research assistant for the $\mathrm{IC}^{2}$ Institute, she recently completed a study of Ecuador's innovation ecosystem.

Gregory Pogue is Interim Deputy Director and Senior Research Scientist at the $\mathrm{IC}^{2}$ Institute of The University of Texas at Austin, where he leads research and implementation programs surrounding technology commercialization, early venture creation and entrepreneurship.

Clay Spinuzzi is a professor of rhetoric and writing at the University of Texas at Austin. He studies how people organize, communicate, collaborate, and innovate at work. Spinuzzi has conducted multiple workplace studies, resulting in several articles and four books.

(C) 2015 IEEE. Personal use of this material is permitted. Permission from IEEE must be obtained for all other uses, in any current or future media, including reprinting/republishing this material for advertising or promotional purposes, creating new collective works, for resale or redistribution to servers or lists, or reuse of any copyrighted component of this work in other works. 